\title{
A growing sense of well-being:
}

a literature review on the complex framework well-being.

M.P. van de Weijer ${ }^{1,3 \#}$, B.M.L. Baselmans ${ }^{1 \# *}$, W. van der Deijl $1^{4}$, M. Bartels ${ }^{1,2,3}$

${ }^{1}$ Department of Biological Psychology, Vrije Universiteit Amsterdam, the Netherlands

${ }^{2}$ Amsterdam Public Health Research Institute, Vrije Universiteit Amsterdam, the Netherlands

${ }^{3}$ Neuroscience Amsterdam, Amsterdam, the Netherlands

${ }^{4}$ Centre de Recherche en Ethique, Université de Montreal, Canada

${ }^{\#}$ These authors contributed equally

${ }^{*}$ Corresponding author B.M.L. Baselmans, Vrije Universiteit Amsterdam, Department of Biological Psychology, Van der Boechorststraat 1, 1081 BT Amsterdam, The Netherlands. T: +31205982971. Email: b.m.l.baselmans@vu.nl 


\begin{abstract}
This review examines the origin and structure of the complex well-being (WB) concept as it is currently applied in behavioral and social sciences. Current research on WB is often divided into two perspectives: subjective well-being (SWB) and psychological well-being (PWB), shaped by the philosophical concepts of hedonism and eudaimonism, respectively. How these different views relate to each other and to WB as a whole has not yet been clearly defined, leading to difficulties in interpretation. In this review, we aim to get more insight into the relation between SWB and PWB. We first present an overview of the philosophical history of SWB and PWB, followed by a systematic literature review. The goal of this review, based on 29 studies, was to investigate how much evidence there is for a conceptual overlap between SWB and PWB. A majority of the studies found appreciable shared variance between the constructs, suggesting that they might be more closely related than previously assumed. On the other hand, evidence from biological studies provides mixed results: a distinction between SWB and PWB based on unique biomarkers is reported, while recent molecular genetic studies show strong genomic overlap between SWB and PWB, but different gene-expression regulation. We end with a discussion on how these findings fit into a well-being framework, and describe some of the issues in the well-being field as we encountered them in our review followed by potential solutions to these problems.
\end{abstract}

KEYWORDS: Eudaimonia, Hedonism, Psychological well-being, Subjective Well-being, Philosophy 


\section{INTRODUCTION}

Over the past 20 years, the positive psychology movement has gained a lot of attention and popularity. This line of research examines the underpinnings of happiness and well-being (Warren \& Donaldson, 2017). From a theoretical perspective, two types of well-being can predominantly be distinguished in the field of positive psychology: subjective well-being (SWB) and psychological well-being (PWB). This distinction, though, has been discussed and criticized based on findings that indicate a substantial conceptual and, in some cases, biological overlap (Kashdan, Biswas-Diener, \& King, 2008; Ryff, Singer, \& Love, 2004). Moreover, with increasing numbers of concepts, constructs, and measurement instruments available (Dodge, Daly, Huyton, \& Sanders, 2012), it has become ambiguous what we mean exactly when we claim to be measuring well-being. Furthermore, one of the largest complications in present-day wellbeing research is conceptual uncertainty: the validity of well-being constructs depends on which theory on the nature of well-being is correct (van der Deijl, 2016). Many theories have been proposed on the nature of well-being, yet, there is no unifying system that brings the different theories together (Alexandrova, 2012, 2015). To continue development in the area of well-being research, we must solve these issues. In this review, we aim to examine the complex framework well-being in three steps. First, we provide a brief overview of the philosophical roots of well-being and how this has shaped the modern SWB and PWB dimensions. Secondly, we perform a systematic literature review aimed at analyzing the current view on the relation between SWB and PWB. Lastly, we discuss the implications of the results from part 2, and offer suggestions for future well-being research.

\section{PART 1 - THE PHILOSOPHICAL HISTORY OF WELL-BEING}

For centuries, people have asked themselves questions about the nature well-being. This can be traced back to ancient Greek philosophers, such as Aristotle and Socrates, who already wondered about the prerequisites for living a good life (Lambert, Passmore, \& Holder, 2015). In this part, we examine the 
ancient history of hedonic- and eudaimonic well-being, followed by a discussion on how this history shaped present-day well-being theories.

\section{Hedonia}

"Pleasure is our first and kindred good. It is the starting-point of every choice and of every aversion, and to it we come back, inasmuch as we make feeling the rule by which to judge of every good thing"(Letter to Menoeceus, Epicurus).

Ancient hedonism is centered around pleasure, or how good a person feels about his or her life (BiswasDiener, Kashdan, \& King, 2009). From this perspective, well-being consists in the balance of pleasure over pain, that is: how to maximize pleasure and minimize pain. Aristippus (c. 435 - c. 356 BCE), one of Socrates' students, was the founder of the Cyrenaic school of Philosophy, a school that taught that pleasure was the ultimate goal of human life and that the pursuit of pleasure was the purpose of human existence and is therefore considered one of the first that taught the hedonistic line of thought (Berryman, 2016). Epicurus popularized the same view on the good life but, different from the Cyrenaics, believed that pleasure was to be found in the absence of desire, and limiting what one wants, rather than striving to satisfy all one's desires as they are.

More recent examples of hedonists are Jeremy Bentham (1748-1832) and John Stuart Mill (18061873). Their emphasis on well-being as pleasure resulted from their utilitarian view on ethics, according to which one should maximize total well-being, rather than as a means to make one's own life good (Tännsjö, 2007). According to Bentham's narrow hedonism, different pains and pleasures possess different values, and their sum determines a person's hedonic level, his or her level of well-being. The two most fundamental aspects in this theory are duration and intensity: these factors determine the value of an individuals' pleasures and pains (Crimmins, 2017). That is to say, the higher the intensity, and the longer the duration, the higher the value of a pain or pleasure. However, according to Mill, this form of hedonism lacks a dimension: quality. His objection to Bentham is that "It is better to be a human being 
dissatisfied than a pig satisfied; better to be Socrates dissatisfied than a fool satisfied" (West, 2004). This implies that well-being is not a mere summation of quantities of pleasure, but that qualitatively better pleasures contribute more to well-being.

\section{From hedonism to subjective well-being}

Comparing these 19th century philosophers with their ancient counterparts, we see a more careful and detailed analysis of the concept of hedonic happiness. In modern-day behavioral and social sciences, the term hedonic well-being is becoming less and less frequent. However, this does not mean that the hedonistic line of thought is unpopular among contemporary social scientists. Rather, we observe a shift in terminology: contemporary social scientists prefer to use the terms subjective well-being (SWB) or happiness rather than pleasure and hedonism. A likely reason for this shift is that hedonism is a philosophical concept that has no clear method of measurement. Therefore, researchers have tried to redefine hedonism into an operational definition. While many methods have been proposed for measuring and conceptualizing SWB (Linton, Dieppe, \& Medina-Lara, 2016), a widely adopted definition is that of Diener (1984). According to this conceptualization, SWB consists of three hallmarks: 1) it is subjective (objective influences are not necessarily part of the construct); 2) it includes positive measures (it is not just the absence of negative factors), and; 3) it includes a global assessment of all aspects of a person's life, not just of one or a few domains. Three separate components are used to measure this construct: positive affect, negative affect, and life satisfaction (Diener, Emmons, Larsen, \& Griffin, 1985). While the ancient concept of happiness is not exactly the same as modern SWB, evidence is pointing towards SWB existing as a result of the hedonic concept of well-being. Conceptually, positive and negative affect, collectively referred to as the affective/emotional aspect of SWB, are similar to the ancient ideas of pains and pleasures contributing to hedonic levels. Life satisfaction (also referred to as the cognitive component of SWB), defined as a global judgment of one's life, could intuitively be comparable to the overall hedonic level of an individual over his/her life as a whole, but life satisfaction could also be considered a newer addition to this type of well-being and not strictly a hedonic concept. A person's hedonic state is 
the overall balance of pleasure and pain experienced at a particular point in time. In contrast, life satisfaction is an evaluation a person makes about his or her life by his or her own standards. These two concepts do not necessarily coincide, as a person may be satisfied with states that might not feel good, like in the context of childbirth (Feldman, 2010). Moreover, in his Conditions of Happiness, Veenhoven (1984) mentions that ancient hedonists equate the evaluation of happiness with a focus on sensory pleasures, while the modern-day conception of happiness more strongly focuses on affective and cognitive pleasures. Taken together, while hedonic levels of well-being are an important aspect of SWB, it does not capture the complete SWB construct.

\section{Eudaimonia}

"Again, our definition accords with the description of the happy man as one who 'lives well' or 'does well'; for it has virtually identified happiness with a form of good life or doing well"(Aristotle, Nicomachean Ethics, trans. H. Rackham (Harvard University Press: London, 1943), 1098b).

Eudaimonia is a Greek word commonly translated as well-being or flourishing. Synonyms for eudaimonia are living well or doing well. Ancient eudaimonic philosophers based their ethical theories on the concept of eudaimonia (Vitters $\varnothing, 2016$ ), and ancient eudaimonism takes well-being to be constituted by virtue and the fulfillment of human capacities. Whereas the hedonic tradition limited the concept of well-being to the balance of pleasure and pain, the eudaimonic tradition takes virtuous activity to be necessary for wellbeing as well. While hedonistic philosophers, such as Epicurus and Mill, may make space for virtue as a prerequisite or contributor to well-being, they do not take it to be necessary or essential for well-being (Vitters $\emptyset$, 2016). Perhaps a more characterizing feature of the eudaimonic tradition of well-being is the principle of self-fulfillment. The most important contributor to, as well as founder of, the eudaimonic line of thought as discussed in this paper, is Aristotle (c. 384 - c. 322 BCE). Aristotle rejected the hedonistic definition of well-being, describing it as "vulgar" (Waterman, 1990). According to Aristotle, well-being 
can be interpreted as well-living: it is about the actualization of human potential. Virtue, defined as knowledge (practiced over time) about how to live well, is an important aspect of this theory (McMahon, 2016). . Therefore, the Aristotelian conception of well-being has more to do with the fulfillment of a person's nature: it aims at reaching one's fullest potential in line with one's deeper principles (Huta \& Ryan, 2010). Whereas hedonists have a purely individualistic notion of well-being, eudaimonia requires living well in one's social environment. A more modern, famous account that is strongly inspired by this conception is Maslow's hierarchy of needs, as proposed by Abraham Maslow (1943). This theory describes five different stages of human growth, starting at the most basic level of physiological needs. Every time the need belonging to a particular level is fulfilled, one moves up a stage in the hierarchy. The highest level a person can reach is self-actualization, which is (according to Maslow) only reached by one in a hundred people. In his theory of human motivation Maslow refers to self-actualization in the sense of the Aristotelian tradition: "It refers to the desire for self-fulfillment, namely, to the tendency for him to become actualized in what he is potentially. This tendency might be phrased as the desire to become more and more what one is, to become everything that one is capable of becoming."

\section{From eudaimonia to psychological well-being}

Where the hedonic line of thought has largely been replaced by SWB in the empirical literature, the eudaimonic tradition has gradually shifted towards psychological well-being (PWB). Whilst creating valid measurement methods for SWB was starting to gain popularity amongst the social sciences around the 1970/1980s, valid measurements for PWB seemed to be lacking at that time. Especially the absence of self-actualization within PWB conceptualization was troubling and gave rise to a new formulation for capturing this construct (Ryff \& Singer, 2008). This new formulation for PWB consists of six core dimensions: Self-Acceptance, Positive Relations with Others, Autonomy, Environmental Mastery, Purpose in Life, and Personal Growth. While many other measurement instruments for PWB are available nowadays, these six core dimensions are still widely used to assess PWB. Notably, there are other modern perspectives on eudaimonia, such as Self-Determination theory (Ryan \& Deci, 2000). However, here, we 
only present the PWB formulation as proposed by Ryff due to its frequent application in behavioral and social sciences. PWB, as proposed by Ryff, is without doubt a result of eudaimonic thinking: it was in her intention to create a measure that captures the eudaimonic line of thought: "Indeed, the deeper philosophical roots of the new model of well-being resided in Aristotle's formulation of the highest human good, which in his Nichomachean Ethics he termed eudaimonia" (Ryff, 2014). Therefore both PWB and eudaimonia are predominantly concerned with the development and self-realization of an individual (Ryff \& Singer, 2008). However, a difference that can be pointed out between ancient eudaimonism and PWB is that in the Aristotelian tradition, eudaimonia did not just concern subjective experience, but intersubjective experience: a way of being in the world (Fowers \& Lefevor, 2015). Ryff's PWB scales, though, still have more focus on the subjective, individualistic values. This is not surprising since Western countries (in which Ryff's scales are often applied) mostly have individualistic values instead of collectivistic ones. The most intersubjective scale is the positive relations with others scale. While this scale does measure the concern someone has for others, it does not place as large emphasis on intersubjective values as the ancient eudaimonic tradition.

\section{PART 2 - SYSTEMATIC LITERATURE REVIEW}

In this review, we chose to adopt the following definitions (see Figure 1):

Subjective Well-Being. The term "subjective well-being" is used to refer to the domain of well-being inspired by the hedonistic line of thought. Unfortunately, the literature on well-being does not often distinguish between two notions of subjective: 1) subjectivity as pertaining to things internal to the individual, and 2) subjective as dependence on a person's attitudes (Brülde, 2007). We adopt the definition as proposed by Diener (1994), that splits subjective well-being into two domains: a cognitive domain and an affective domain. The cognitive domain is comprised of a person's general evaluation of his or her life. This domain can also be referred to as an individual's satisfaction with life. The affective 
domain refers to a person's long-term levels of negative and positive affect, in line with option (1) pertaining to subjectivity mentioned above.

Psychological Well-Being. The term "psychological well-being" is used to refer to the domain of wellbeing inspired by the eudaimonic line of thought. For the purpose of this paper, we refer to the formulation as proposed by Ryff (1995) where psychological well-being consists of the six core elements: 1) self-acceptance; knowing and accepting oneself, 2) positive relations with others, reflecting one's ability to empathize and to show affection, 3) autonomy; a sense of independence, 4) environmental mastery; the capacity to manage one's life and the surrounding world, 5) purpose in life, the belief that someone's life is purposeful, and 6) personal growth; the development of personal potential. Moreover, we consider "self-actualization", referring to the realization/fulfillment of one's potential, as a term employed to refer to psychological well-being (even though in a more restricted sense than Ryff's definition).

\section{GOALS OF THE REVIEW}

We conducted a systematic literature review with the goal of analyzing how the structure of well-being is currently viewed and measured. The goal of the review was to answer the following question: "How much evidence is there for a conceptual overlap between SWB and PWB?" For this purpose, we reviewed studies examining the relationship between SWB and PWB or the general structure of well-being.

\section{METHOD}

\section{Search Strategy}

The search terms were entered into the electronic databases Web of Science and PubMed at 08-01-2018. Since many terms are used interchangeably in the well-being field, we selected different search terms for PWB and SWB in order to include as many relevant studies as possible. Table 1 shows the search terms used for the search. Every search included an entry of two search terms simultaneously. The terms in 
column 1 were entered in combination with the terms in column 2. Moreover, the terms in column 1 were entered in combination with each other, as well as the terms in column 2, which were also entered together using different combinations. The first author performed the literature search. A second assessor double-checked a random sample of 200 articles. Cohen's K was calculated to formally assess the degree of agree of inter-rater agreement.

\section{Inclusion Criteria}

Studies were included if they made some type of empirical comparison between psychological and subjective well-being. Meta-analyses, literature surveys, and theoretical papers were excluded from the review. Since well-being is under relatively different influences and genetically less stable in childhood and adolescence compared to adulthood (Baselmans et al., submitted), we only included studies in which the mean age of the participants was 18 or higher. Furthermore, since individualistic, Western countries value different things with respect to well-being and apply different standards than countries with a collectivistic/eastern culture, we decided to only include countries that can be categorized as Western (Joshanloo, 2014). This included: Europe, the USA, Canada, and Australia. The paper has to be written in English and, in order to ensure the quality of the paper, be published in a peer-reviewed journal. In order to get the broadest scope of information, we did not apply any constraints regarding the time frame in which the studies were published. When age or origin of the participants could not be derived from a paper, it was excluded to prevent bias from unknown factors.

\section{RESULTS}

Figure 2 displays a flowchart depicting the search process. The inter-rater agreement was $91 \%$. There was moderate agreement between the two assessors $(\kappa=.452,95 \%$ C.I., 0.210 to $0.694, p=.002)$. The initial electronic database search resulted in 774 hits in PubMed and 2528 hits in Web of Science. After removing the duplicates from the two searches together, we ended with a list of 2644 articles. After scanning the abstracts and titles of these 2644 articles based on the selection criteria mentioned above, we 
were left with 178 articles. These articles were examined in greater detail by reading them fully. Eventually, 29 articles met our selection criteria and were thus included in the study. Broadly, the resulting articles could be split up in three domains: 1) correlational studies, 2) studies looking at the factor structure of well-being, and 3) studies looking at biological/genetic factors influencing well-being. Therefore, we present our results for these domains separately. Importantly, we focused on the measurement instruments used in a study and the descriptions of the constructs as provided by the authors rather than the names used for the constructs. The reason for this approach is that there seems to be an inconsistent use of terminology in the field of well-being. For example, sometimes, hedonic measures are referred to as psychological well-being. Categorizing the constructs under the names provided by different authors in this review would therefore lead to false comparisons. An overview of all the different measurement instruments used to measure well-being in these studies can be found in Table 2 .

\section{Correlational Studies}

Table 3 shows the three studies that fell under the category "correlational studies". Important in this table (and the following tables) is that the column named "research question" denotes the (sub)question in this study relevant for the purpose of this literature review. This means that the questions in this column do not necessarily reflect the main question in a study. From the studies in Table 3, one (nr 1) study suggests that the two constructs share considerable overlap, but are also distinguishable. In this study, personal expressiveness (their measure of eudaimonia) was a sufficient, but not a necessary condition for hedonic happiness. Furthermore, one (nr 2) study found that the relationship between life satisfaction and 4 of the 6 PWB scales was mediated by affect balance. The remaining two PWB scales were nevertheless also associated with life satisfaction. Lastly, one (nr 3) study suggests that PWB and SWB might not be as separated as previously claimed. In this study, this was suggested because of the highly similar patterns of social reputations, clinician judgments, and behaviors associated with self-reports of subjective happiness and psychological well-being. These mixed results show that correlational analyses do not provide us 
with enough information to draw conclusions about the relationship between eudaimonic and hedonic well-being.

\section{Studies examining the factor structure of well-being}

Table 4 shows the 17 studies that fell under the category "studies examining the factor structure of wellbeing". These studies made use of several analyses, including: exploratory and confirmatory factor analysis (EFA and CFA), structural equation modeling, and Bayesian structural equation models. In this domain, a variety of models was tested. Five studies ( $\mathrm{nr} 5,13,17,18$, and 19) approached well-being from Keyes' perspective, in which a three-factor model was tested with emotional, social, and psychological well-being as sub-domains of well-being (Keyes, 2002). Since the emotional domain in Keyes' model is an indicator of hedonic well-being, we decided these studies were relevant for the purpose of this study as well. One of these studies (nr 19) even labels the three-factor model as such, with the sub-domains subjective, psychological, and social well-being. These studies all conclude that the three-factor model is an appropriate fit to their data. According to these studies, well-being can most accurately be measured by considering these three dimensions simultaneously. An interesting finding was that in study 5 and 19, exploratory structural equation modeling was used and compared to CFA. The authors of this study conclude that CFA results in inflated inter-factor correlations, thereby overestimating the correlations between SWB and PWB domains, suggesting potential inflation in the inter-factor correlations for the studies in this review that made use of CFA. Eleven (nr 4, 6, 7, 8, 10, 11, 12, 14, 15, 16, and 19) studies approached well-being from a two-domain perspective, with SWB/ hedonic wellbeing as one domain, and PWB/eudaimonic well-being as the other. The conclusions from these studies were in agreement: PWB and SWB are overlapping, yet distinguishable constructs. Interestingly, one of these studies ( $\mathrm{nr} 4$ ) found that the cognitive aspect of SWB was more closely related to eudaimonic wellbeing than to the affective aspect of SWB. This further demonstrates the interrelatedness of the constructs. The remaining study (nr 9) examined well-being as consisting of the domains: SWB, personal growth, religiosity. In this study, evidence was found for this tripartite structure. 


\section{Studies examining biological/genetic factors of well-being}

Table 5 shows the 10 studies that fell under the category "studies examining biological/genetic factors of well-being”. Note that the two studies by Fredrickson et al. (2013 and 2015) have been the subject of discussion and that two critiques on this paper are also included in the review. Again, we observe differences between the conclusions from these studies. From the seven biological studies (the two critiques not included), six (nr 20,22, 24, 26, 28 and 29) found evidence for distinct biological factors influencing SWB and PWB and one (nr 25) found evidence for a shared biological factor. These studies included a wide range of biological factors, such as CTRA gene expression profile ( $\mathrm{nr} 20,22,29)$, neural activation patterns ( $\mathrm{nr} 25)$ and inflammatory factors ( $\mathrm{nr} 24,26)$. The only twin-family design included (nr 27) found evidence for a single genetic factor and some trait-specific genetic factors. Together, these studies suggest overlap as well as distinctiveness between the SWB and PWB.

\section{How much evidence is there for a conceptual overlap between SWB and PWB?}

This literature review consisted of 29 studies investigating the conceptual overlap between SWB and PWB that could be split up into the following domains: correlational studies, studies examining the factor structure of well-being, and studies examining biological/genetic factors of well-being. The results from this review show that:

- Studies employing correlational analyses provide us with mixed results and cannot be used to infer clear conclusions about the relationship between SWB and PWB.

- Studies examining the factor structure of well-being find that there is a large overlap between PWB and SWB, but that the constructs can also be distinguished based on considerable unshared variances.

- Studies examining biological/genetic factors of well-being found evidence for distinct biological factors associated with the traits. However, there was also evidence for a single genetic factor influencing PWB and SWB. 


\section{PART 3 - DISCUSSION, ISSUES AND RECOMMENDATIONS}

In this review, we examined the complex framework of well-being. The first part of the review provides a brief review of the philosophical history of hedonism and eudaimonism, the two philosophical disciplines that inspired researchers to start operationalizing and measuring SWB and PWB. In the second part of the review, we sought to investigate what empirical research can tell us about the distinction between the two constructs by conducting a systematic literature review. The review consisted only of studies directly examining the relationship between the two constructs. These studies employed correlational, factor analytical, and biological methods to assess to what extent the two constructs can be separated or united. The high correlations between the constructs showed that there is indeed overlap between them. However, considering the distinct biological correlates and the fact that the two constructs both explain unique as well as overlapping parts of the variance in "general" well-being, these studies also showed that PWB and SWB can be distinguished. In this part of the review, we will discuss the implications of the review and formulate some recommendations based on these implications. Lastly, we provide some general recommendations for follow-up research that could extend the findings from the current search.

\section{Issue 1: The relationship between philosophical constructs and psychological measures}

When ancient philosophers started defining hedonism and eudaimonism, their definitions and ideas were not designed to ensure they could be translated into measurable constructs. It is therefore not surprising that measuring well-being (subjective or psychological) has turned out to be a complex task. This is evident when looking at Table 2. Especially for SWB, the amount of measurement instruments applied is extensive. It is clear that there is a lack of consensus amongst researchers concerning the measurement of well-being. A question one could raise is whether the current distinction between SWB and PWB might be a result of the ancient distinction between hedonism and eudaimonism. Since measurement instruments 
are only as reliable as the theories underlying them, this would mean that most of these instruments might not be measuring the constructs they ought to measure.

\section{Recommendation 1: Re-define the framework}

The literature searches in this review revealed that SWB and PWB are largely overlapping, but also partly distinct. This suggests that the distinction between SWB and PWB is not as large as proposed by the theories underlying them. The ancient separation between hedonism and eudaimonism can be explained from the (data-free) theoretical philosophical perspective, but cannot accurately be captured by questionnaires employed in modern-day social/behavioral research. While the traditional view of hedonism and eudaimonism has been very important in terms of its contribution to the theoretical framework, it fails to provide sufficient guidance for the formulation of empirical constructs. We propose that an empirical well-being framework should be developed considering the actual empirical data rather than the ideas that inspired the research (Alexandrova, 2012). In the context of the social and behavioral sciences, the well-being framework can best be described as one hierarchical construct including both SWB and PWB constructs. This means that hedonism and eudaimonism are not to be defined as two clearly separated streams, but as related underlying domains of the same construct.

\section{Issue 2: Semantic Ambiguity and Inconsistency - do we mean the same things?}

It is often taken for granted that when we are using the same words, we mean the same things. As it turns out, at least in the field of well-being, we should be more cautious about this assumption. An obvious issue we encountered in our search was the inconsistent use of terminology. The problem as we encountered it was twofold: First, there was a diverse range of terms used to denote similar concepts. Second, the terms were used in an inconsistent manner. The first problem, that of diversity, is the least problematic. We dealt with this problem in the early stages of the review, where we used a variety of terms to expand our search. For example, SWB can be referred to as "happiness", "hedonism", "subjective happiness", "emotional well-being" and "affective well-being". The largest consequence of 
this lack of a common language is that it potentially blocks advancement in science since it makes it more difficult for researchers to learn from each other's work. The second issue, that of inconsistency, has more severe consequences. With inconsistency, we refer to the inappropriate application of terminology within and beyond the field as a whole, and sometimes within one study. Often, "subjective well-being" is used to refer to both the psychological as well as the subjective domain of well-being. Presumably, this issue arises due to the fact that both SWB and PWB are measured using questionnaires, meaning that participants will give a subjective evaluation in both cases. The same holds for the term "psychological well-being”. General well-being was often referred to as psychological well-being, which was thereafter split up in multiple domains that could be identified as the PWB and SWB domain. Terms that are used most inconsistently were those that are used less frequent. An example is the term "flourishing", which was sometimes used to denote SWB, sometimes to denote PWB, and sometimes to describe a combination of both. This issue causes confusion in a more severe sense: when not described properly, it could cause readers to draw the wrong conclusions.

\section{Recommendation 2: Be detailed}

Both problems, though one more severe than the other, have the same consequence: confusion. While preventing this inconsistency would be the most effective solution, this is not easily manageable since it would require a consensus concerning the use of terminology in this field. Therefore, the most feasible solution would be for researchers to be detailed about the constructs they aim to be measuring and about the scope of their study. This means that researchers should: 1) be consistent in their use of terminology; 2) give detailed descriptions of their most basic terms and constructs, and; 3) keep in mind that the results of their study might not cover well-being in its entirety. Especially (2) is important, since it can help prevent confusion for the careful reader even if (1) and (3) are not fulfilled. In this way, even if there is no consensus concerning terminology, different studies can more easily be compared and interpreted. 


\section{Follow-up research}

A last issue that has not yet been discussed is that if one were to draw conclusions about "well-being" in general, but only uses measurement instruments related to one domain of well-being, the conclusion would depend on which domain is included (given the partial distinction between the constructs). To evaluate to what extent this might influence research outcomes, it is important for future studies to examine whether SWB and PWB relate to external correlates in the same way and to a similar degree. For example, in a study by Aghababaei \& Arji (2014), the personality domain honesty-humility (H-H) was unrelated to SWB, but related to PWB. This means that if one were to draw conclusions about $\mathrm{H}-\mathrm{H}$ and "well-being" in general, but only used measurement instruments related to one domain of well-being, the conclusion would depend on which domain is included. At the moment, it is not clear whether these types of discrepancies often occur in the literature. Without this knowledge, the safest approach is to take a multifaceted approach and use multiple measurement instruments aimed at SWB and PWB. In this way, researchers can overcome the risk of drawing firm conclusions based on incomplete assessment of wellbeing. In case such an approach is too time- or money-consuming, another solution is to make explicit which domain of well-being the results of a study refer to.

\section{Conclusion}

In this review, we examined the origin and structure of the complex framework well-being as applied in behavioral and social sciences. A systematic literature review was performed that examined how much evidence there is for a conceptual overlap between SWB and PWB. We find that SWB and PWB are related constructs that are likely domains of a general factor well-being. However, while the constructs are related, they are not interchangeable and can be distinguished both conceptually and biologically. In order to continue development in this field of research, we advise to view SWB and PWB as related domains of the same overarching well-being construct. Moreover, to avoid inconsistency and 
confusion, it is important for researchers to be very detailed about the constructs they aim to be measuring and to keep in mind that to measure well-being most accurately, both SWB and PWB should be included.

\section{Acknowledgments}

M. Bartels and B.M.L Baselmans are financially supported by the University Research Chair position of M. Bartels.

\section{Conflict of interest}

The Authors declare that they have no conflict of interest. 
Table 1

Search Terms for Literature search 1

\begin{tabular}{ll}
\hline Term 1 & Term 2 \\
\hline Psychological Well-Being & Happiness \\
Subjective Well-Being & Flourishing \\
& hedon* \\
& eudaimon* \\
\hline
\end{tabular}


Table 2

Measurement Instruments used in studies from the Literature Search

\begin{tabular}{|c|c|c|c|c|c|}
\hline \multicolumn{3}{|c|}{ Subjective Well-Being Measures } & \multicolumn{3}{|c|}{ Psychological Well-Being } \\
\hline Instrument & Studies & Total & Instrument & Studies & Total \\
\hline $\begin{array}{l}\text { The Satisfaction } \\
\text { with Life Scale }\end{array}$ & $\begin{array}{l}\text { Sanjuan, 2011; Vanhoutte } \\
\text { \& Nazroo, 2014; } \\
\text { McMahan \& Estes, 2011; } \\
\text { Compton, 2001; Chen, } \\
\text { Jing, Hayes, \& Lee, 2013; } \\
\text { Huta \& Ryan, 2010; } \\
\text { Kafka \& Kozma, 2002; } \\
\text { Urry et al., 2004; } \\
\text { Compton, Smith, } \\
\text { Cornish, \& Qualls, } 1996 .\end{array}$ & 18 & $\begin{array}{l}\text { Ryff's Scales of } \\
\text { Psychological } \\
\text { Well-being } \\
\text { (several versions } \\
\text { with varying } \\
\text { amount of items) }\end{array}$ & $\begin{array}{l}\text { Ryff, Singer, \& Love, 2004; } \\
\text { Sanjuan, 2011; Nave, } \\
\text { Sherman, \& Funder, 2008; } \\
\text { Joshanloo, 2016; Compton, } \\
\text { 2001; Keyes, Shmotkin, \& } \\
\text { Ryff, 2002; Chen, Jing, } \\
\text { Hayes, \& Lee, 2013; } \\
\text { Gallagher, Lopez, \& } \\
\text { Preacher, 2009; Kafka \& } \\
\text { Kozma, 2002; Kokko, } \\
\text { Korkalainen, Lyyra, \& Feldt, } \\
\text { 2013; Robitschek \& Keyes, } \\
\text { 2009; Fredrickson et al., } \\
\text { 2015; Friedman, Hayney, } \\
\text { Love, Singer, \& Ryff, 2007; } \\
\text { Urry et al., 2004; Keyes, } \\
\text { Myers, \& Kendler, 2010; } \\
\text { Walker, 2016, Compton, } \\
\text { Smith, Cornish, \& Qualls, } \\
\text { 1996; Joshanloo, 2017. }\end{array}$ & 28 \\
\hline $\begin{array}{l}\text { The Positive and } \\
\text { Negative Affect } \\
\text { Scale }\end{array}$ & $\begin{array}{l}\text { Ryff, Singer, \& Love, } \\
\text { 2004; Sanjuan, 2011; } \\
\text { Burns, Anstey, \& } \\
\text { Windsor, 2011; Chen, } \\
\text { Jing, Hayes, \& Lee, 2013; } \\
\text { Gallagher, Lopez, \& } \\
\text { Preacher, 2009; Urry et } \\
\text { al., 2004. }\end{array}$ & 12 & $\begin{array}{l}\text { The Personally } \\
\text { Expressive } \\
\text { Activities } \\
\text { Questionnaire }\end{array}$ & Waterman, 1993. & 1 \\
\hline $\begin{array}{l}\text { The short-form } \\
\text { MASQ }\end{array}$ & $\begin{array}{l}\text { Ryff, Singer, \& Love, } \\
2004 .\end{array}$ & 1 & The CASP scale & Vanhoutte \& Nazroo, 2014. & 1 \\
\hline $\begin{array}{l}\text { The Personally } \\
\text { Expressive } \\
\text { Activities } \\
\text { Questionnaire }\end{array}$ & Waterman, 1993. & 1 & $\begin{array}{l}\text { Beliefs about } \\
\text { Well-Being Scale }\end{array}$ & McMahan \& Estes, 2011. & 1 \\
\hline $\begin{array}{l}\text { The Subjective } \\
\text { Happiness Scale }\end{array}$ & $\begin{array}{l}\text { Nave, Sherman, \& } \\
\text { Funder, 2008; Gallagher, } \\
\text { Lopez, \& Preacher, } 2009 .\end{array}$ & 3 & $\begin{array}{l}\text { The Meaning in } \\
\text { Life } \\
\text { Questionnaire- } \\
\text { Presence Subscale }\end{array}$ & McMahan \& Estes, 2011. & 1 \\
\hline $\begin{array}{l}\text { the General } \\
\text { Health } \\
\text { Questionnaire }\end{array}$ & $\begin{array}{l}\text { Vanhoutte \& Nazroo, } \\
2014 .\end{array}$ & 1 & $\begin{array}{l}\text { The Subjective } \\
\text { Vitality Scale }\end{array}$ & $\begin{array}{l}\text { McMahan \& Estes, 2011; } \\
\text { Huta \& Ryan, } 2010 .\end{array}$ & 2 \\
\hline the CES-D & $\begin{array}{l}\text { Vanhoutte \& Nazroo, } \\
2014 .\end{array}$ & 1 & $\begin{array}{l}\text { The hedonic and } \\
\text { eudaimonic }\end{array}$ & $\begin{array}{l}\text { Bujacz, Vitterso, Huta, \& } \\
\text { Kaczmarek, } 2014 .\end{array}$ & 1 \\
\hline
\end{tabular}




\begin{tabular}{|c|c|c|c|c|c|}
\hline & & & $\begin{array}{l}\text { motives for } \\
\text { activities scale }\end{array}$ & & \\
\hline $\begin{array}{l}\text { Mroczek and } \\
\text { Kolarz's positive } \\
\text { and negative } \\
\text { affect scales } \\
\end{array}$ & $\begin{array}{l}\text { Joshanloo, 2016; } \\
\text { Joshanloo, } 2017 .\end{array}$ & 1 & $\begin{array}{l}\text { Connor-Davidson } \\
\text { Resilience Scale } \\
\text { \& Personal } \\
\text { Mastery Scale }\end{array}$ & $\begin{array}{l}\text { Burns, Anstey, \& Windsor, } \\
2011 .\end{array}$ & 1 \\
\hline $\begin{array}{l}\text { Satisfaction with } \\
\text { Life: unspecified } \\
\text { Instrument }\end{array}$ & $\begin{array}{l}\text { Joshanloo, 2016; } \\
\text { Joshanloo, } 2017 .\end{array}$ & 2 & $\begin{array}{l}\text { Meaning \& } \\
\text { elevating } \\
\text { experience as } \\
\text { assessed with a } \\
\text { self-created scale. }\end{array}$ & Huta \& Ryan, 2010. & 1 \\
\hline $\begin{array}{l}\text { Beliefs about } \\
\text { Well-Being Scale }\end{array}$ & McMahan \& Estes, 2011. & 1 & $\begin{array}{l}\text { "11 Well-Being } \\
\text { items measuring } \\
\text { the frequency of } \\
\text { negative and } \\
\text { postive affect \& } \\
\text { evaluation of } \\
\text { people's lifes" }\end{array}$ & $\begin{array}{l}\text { Kim, Lehning, \& Sacco, } \\
2016 .\end{array}$ & 1 \\
\hline $\begin{array}{l}\text { the Intensity and } \\
\text { Time Affect Scale }\end{array}$ & McMahan \& Estes, 2011. & 1 & $\begin{array}{l}\text { The Short } \\
\text { Flourishing Scale }\end{array}$ & $\begin{array}{l}\text { Fredrickson et al., 2013; } \\
\text { Walker, } 2016 .\end{array}$ & 2 \\
\hline $\begin{array}{l}\text { The hedonic and } \\
\text { eudaimonic } \\
\text { motives for } \\
\text { activities scale }\end{array}$ & $\begin{array}{l}\text { Bujacz, Vitterso, Huta, \& } \\
\text { Kaczmarek, } 2014 .\end{array}$ & 1 & $\begin{array}{l}\text { Mental Health } \\
\text { Continuum- } \\
\text { Short Form } \\
\end{array}$ & $\begin{array}{l}\text { Fredrickson et al., 2015; } \\
\text { Walker, } 2016 .\end{array}$ & 2 \\
\hline $\begin{array}{l}\text { The Happiness } \\
\text { Measure }\end{array}$ & $\begin{array}{l}\text { Compton, 2001; } \\
\text { Compton, Smith, } \\
\text { Cornish, \& Qualls, } 1996 .\end{array}$ & 3 & the CASP-19 & $\begin{array}{l}\text { Steptoe, Demakakos, de } \\
\text { Oliveira, \& Wardle, } 2012 .\end{array}$ & 1 \\
\hline $\begin{array}{l}\text { The Affect } \\
\text { Balance Scale }\end{array}$ & Compton, 2001. & 1 & $\begin{array}{l}\text { The Short Index } \\
\text { of Self- } \\
\text { Actualization }\end{array}$ & $\begin{array}{l}\text { Compton, Smith, Cornish, \& } \\
\text { Qualls, } 1996 .\end{array}$ & 2 \\
\hline $\begin{array}{l}\text { Cantril's Self- } \\
\text { Anchoring Scale }\end{array}$ & $\begin{array}{l}\text { Keyes, Shmotkin, \& } \\
\text { Ryff, } 2002 .\end{array}$ & 1 & $\begin{array}{l}\text { the Perceived Self } \\
\text { Questionnaire }\end{array}$ & $\begin{array}{l}\text { Compton, Smith, Cornish, \& } \\
\text { Qualls, } 1996 .\end{array}$ & 2 \\
\hline $\begin{array}{l}\text { The Midlife } \\
\text { Development } \\
\text { Inventory affect } \\
\text { scales }\end{array}$ & $\begin{array}{l}\text { Keyes, Shmotkin, \& } \\
\text { Ryff, 2002; Gallagher, } \\
\text { Lopez, \& Preacher, } 2009 .\end{array}$ & 2 & & & \\
\hline The HEMA & Huta \& Ryan, 2010. & 1 & & & \\
\hline $\begin{array}{l}\text { the brief NA and } \\
\text { PA scales } \\
\text { developed by } \\
\text { Diener and } \\
\text { Emmons }\end{array}$ & Huta \& Ryan, 2010. & 1 & & & \\
\hline $\begin{array}{l}\text { The Memorial } \\
\text { University of } \\
\text { Newfoundland } \\
\text { Scale of } \\
\text { Happiness }\end{array}$ & Kafka \& Kozma, 2002. & 1 & & & \\
\hline $\begin{array}{l}\text { "11 Well-Being } \\
\text { items measuring } \\
\text { the frequency of } \\
\text { negative and } \\
\text { postive affect \& } \\
\text { evaluation of } \\
\text { people's lifes" }\end{array}$ & $\begin{array}{l}\text { Kim, Lehning, \& Sacco, } \\
2016 .\end{array}$ & 1 & & & \\
\hline
\end{tabular}




\begin{tabular}{|c|c|c|c|c|}
\hline $\begin{array}{l}\text { the Brief Mood } \\
\text { Introspection } \\
\text { Scale }\end{array}$ & $\begin{array}{l}\text { Kokko, Korkalainen, } \\
\text { Lyyra, \& Feldt, } 2013 .\end{array}$ & 1 & & \\
\hline $\begin{array}{l}\text { the Life Situation } \\
\text { Questionnaire }\end{array}$ & $\begin{array}{l}\text { Kokko, Korkalainen, } \\
\text { Lyyra, \& Feldt, } 2013 .\end{array}$ & 1 & & \\
\hline $\begin{array}{l}\text { A Personal } \\
\text { Interview }\end{array}$ & $\begin{array}{l}\text { Kokko, Korkalainen, } \\
\text { Lyyra, \& Feldt, } 2013 .\end{array}$ & 1 & & \\
\hline $\begin{array}{l}\text { An adaption of } \\
\text { Cantril's Self- } \\
\text { Anchoring Scale } \\
\& \text { Bradburn's } \\
\text { affect balance } \\
\text { Scale }\end{array}$ & $\begin{array}{l}\text { Robitschek \& Keyes, } \\
2009 .\end{array}$ & 1 & & \\
\hline $\begin{array}{l}\text { The Short } \\
\text { Flourishing Scale }\end{array}$ & $\begin{array}{l}\text { Fredrickson et al., 2013; } \\
\text { Walker, 2016. }\end{array}$ & 2 & & \\
\hline $\begin{array}{l}\text { Mental Health } \\
\text { Continuum-- } \\
\text { Short Form }\end{array}$ & $\begin{array}{l}\text { Fredrickson et al., 2015; } \\
\text { Walker, } 2016 .\end{array}$ & 2 & & \\
\hline $\begin{array}{l}\text { The short-form } \\
\text { Mood and } \\
\text { Anxiety Symptom } \\
\text { Questionnaire }\end{array}$ & $\begin{array}{l}\text { Friedman, Hayney, Love, } \\
\text { Singer, \& Ryff, 2007; } \\
\text { Ryff, Singer, \& Love, } \\
2004 .\end{array}$ & 2 & & \\
\hline $\begin{array}{l}\text { Unspecified: } \\
\text { positive affect \& } \\
\text { Life Satisfaction }\end{array}$ & $\begin{array}{l}\text { Keyes, Myers, \& } \\
\text { Kendler, } 2010 .\end{array}$ & 1 & & \\
\hline the CASP-19 & $\begin{array}{l}\text { Steptoe, Demakakos, de } \\
\text { Oliveira, \& Wardle, } \\
2012 .\end{array}$ & 1 & & \\
\hline $\begin{array}{l}\text { The quality of } \\
\text { life scale }\end{array}$ & $\begin{array}{l}\text { Compton, Smith, } \\
\text { Cornish, \& Qualls, } 1996 .\end{array}$ & 1 & & \\
\hline
\end{tabular}


Table 3

Correlational Studies

\begin{tabular}{|c|c|c|c|c|c|c|}
\hline $\mathrm{Nr}$ & Article & Research Question & Participants & Analysis & Outcome & $\begin{array}{l}\text { The structure of Well- } \\
\text { Being }\end{array}$ \\
\hline 1 & $\begin{array}{l}\text { Waterman, } \\
1993\end{array}$ & $\begin{array}{l}\text { Is it possible to distinguish } \\
\text { between personal } \\
\text { expressiveness (eudaimonia) } \\
\text { and hedonic enjoyment? }\end{array}$ & $\begin{array}{l}\text { Study 1: } N=140 \\
\text { undergraduates (18-23 } \\
\text { years) \& } 69 \text { graduates } \\
\text { (22-65 years). Study 2: } \\
N=193 \text { undergraduates } \\
\text { (18-46 years) \& } 56 \\
\text { graduates (22-52 years) } \\
\text { (Trenton State College) } \\
\end{array}$ & $\begin{array}{l}\text { Correlational } \\
\text { analysis }\end{array}$ & $\begin{array}{l}\text { "Eudaimonia is a sufficient, but } \\
\text { not a necessary condition for } \\
\text { hedonic happiness." }\end{array}$ & $\begin{array}{l}\text { Empirically, hedonic and } \\
\text { eudaimonic enjoyment are } \\
\text { related but can also be } \\
\text { distinguished }\end{array}$ \\
\hline 2 & Sanjuan, 2011 & $\begin{array}{l}\text { How are psychological and } \\
\text { subjective well-being } \\
\text { related? }\end{array}$ & $\begin{array}{l}N=250 \text { Spanish } \\
\text { participants, age }(M= \\
36.46, S D=10.83)\end{array}$ & $\begin{array}{l}\text { Regression } \\
\text { analyses }\end{array}$ & $\begin{array}{l}\text { "The results obtained here show } \\
\text { that experiencing positive } \\
\text { relations with others, autonomy, } \\
\text { purpose in life, and personal } \\
\text { growth is associated with } \\
\text { positive feelings, which, in turn, } \\
\text { leads to judgments of } \\
\text { satisfaction with life." }\end{array}$ & $\begin{array}{l}\text { Psychological and } \\
\text { subjective well-being are } \\
\text { independent, but there is a } \\
\text { strong relationship which } \\
\text { is (for some scales) } \\
\text { mediated by affect } \\
\text { balance. }\end{array}$ \\
\hline 3 & $\begin{array}{l}\text { Nave, Sherman, } \\
\text { \& Funder, } 2008\end{array}$ & $\begin{array}{l}\text { What are the patterns of } \\
\text { social reputations, clinician } \\
\text { judgments and behaviors } \\
\text { associated with self-reports } \\
\text { of subjective happiness (SH) } \\
\text { and psychological well- } \\
\text { being? }\end{array}$ & $\begin{array}{l}N=196 \text { undergraduate } \\
\text { students from the } \\
\text { university of } \\
\text { California-Riverside } \\
\text { (age not reported, mean } \\
\text { age assumed above } 18 \\
\text { due to college sample). }\end{array}$ & $\begin{array}{l}\text { Correlational } \\
\text { analyses }\end{array}$ & $\begin{array}{l}\text { "The results of this study suggest } \\
\text { that the pattern of social } \\
\text { reputations, clinician judgments, } \\
\text { and behaviors associated with } \\
\text { self-reports of SH and PWB are } \\
\text { remarkably similar." }\end{array}$ & $\begin{array}{l}\text { "One might question } \\
\text { whether SH and PWB are } \\
\text { truly distinct } \\
\text { psychological constructs" }\end{array}$ \\
\hline
\end{tabular}


Table 4

Studies examining the factor structure of well-being

\begin{tabular}{|c|c|c|c|c|c|c|}
\hline $\mathrm{Nr}$ & Artikel & Research Question & Participants & Analysis & Outcome & $\begin{array}{l}\text { The structure of Well- } \\
\text { Being }\end{array}$ \\
\hline 4 & Vanhoutte \& Nazroo, 2014 & $\begin{array}{l}\text { To what extent do } \\
\text { empirical measures } \\
\text { confirm to the } \\
\text { theoretical divide } \\
\text { between hedonic and } \\
\text { eudaimonic aspects of } \\
\text { subjective well-being? }\end{array}$ & $\begin{array}{l}N=3703 \text { participants of } \\
\text { the English population, } \\
\text { age }>50\end{array}$ & $\begin{array}{l}\text { Confirmatory } \\
\text { Factor } \\
\text { Analysis } \\
\text { (CFA) }\end{array}$ & $\begin{array}{l}\text { "The difference between } \\
\text { hedonic and eudaimonic } \\
\text { well-being has been } \\
\text { exaggerated in the } \\
\text { literature" }\end{array}$ & $\begin{array}{l}\text { A three-fold structure, } \\
\text { distinguishing affective, } \\
\text { emotional \& eudaimonic } \\
\text { well-being. }\end{array}$ \\
\hline 5 & Joshanloo, 2016 & $\begin{array}{l}\text { What is the relationship } \\
\text { between hedonic and } \\
\text { eudaimonic aspects of } \\
\text { well-being when } \\
\text { investigated with } \\
\text { ESEM (as compared to } \\
\text { CFA)? }\end{array}$ & $\begin{array}{l}N=3986 \text { adults from the } \\
\text { United States, } \\
\text { age }(M=56.12, S D= \\
12.33)\end{array}$ & $\begin{array}{l}\text { CFA \& } \\
\text { Exploratory } \\
\text { Structural } \\
\text { Equation } \\
\text { Modeling } \\
\text { (ESEM) }\end{array}$ & $\begin{array}{l}\text { "The inter-correlations } \\
\text { between well-being } \\
\text { factors may have been } \\
\text { overestimated in the } \\
\text { previous research due to } \\
\text { the inherent limitations of } \\
\text { traditional CFA." }\end{array}$ & $\begin{array}{l}\text { "The hedonic and } \\
\text { eudaimonic factors are } \\
\text { correlated yet distinct } \\
\text { factors, with } \\
\text { considerable unshared } \\
\text { variance." }\end{array}$ \\
\hline 6 & McMahan \& Estes, 2011 & $\begin{array}{l}\text { To what degree do } \\
\text { eudaimonic and } \\
\text { hedonic dimensions of } \\
\text { individual conceptions } \\
\text { of well-being } \\
\text { differentially associate } \\
\text { with self-reported well- } \\
\text { being? }\end{array}$ & $\begin{array}{l}\text { Study } 1: N=115 \\
\text { American } \\
\text { undergraduate students, } \\
\text { age }(M=21, S D=3.71) . \\
\text { Study } 2: N=240 \text { non- } \\
\text { student American } \\
\text { participants, } \\
\text { age }(M=31.9, S D=14.19)\end{array}$ & $\begin{array}{l}\text { Regression } \\
\& \text { CFA }\end{array}$ & $\begin{array}{l}\text { "Eudaimonic dimensions } \\
\text { of conceptions of well- } \\
\text { being are more robustly } \\
\text { associated with } \\
\text { experienced well-being } \\
\text { than hedonic } \\
\text { dimensions." }\end{array}$ & $\begin{array}{l}\text { "Conceptualizing well- } \\
\text { being in eudaimonic } \\
\text { terms may be relatively } \\
\text { more important for } \\
\text { positive psychological } \\
\text { functioning." }\end{array}$ \\
\hline 7 & $\begin{array}{l}\text { Bujacz, Vitterso, Huta, \& } \\
\text { Kaczmarek, } 2014\end{array}$ & $\begin{array}{l}\text { What is the relationship } \\
\text { between factors of } \\
\text { stable hedonic and } \\
\text { eudaimonic orientations } \\
\text { to well-being across } 2 \\
\text { different nations? }\end{array}$ & $\begin{array}{l}N=386 \text { Polish adults, } \\
\text { age }(M=21.26, S D= \\
1.75), 429 \text { North } \\
\text { American Anglophone } \\
\text { participants, } \\
\text { age }(M=19.19, S D=1.92)\end{array}$ & $\begin{array}{l} \\
\text { CFA, } \\
\text { Maximum } \\
\text { Likelihood } \\
\text { estimation \& } \\
\text { Bayesian } \\
\text { Structural } \\
\text { Equation } \\
\text { Models }\end{array}$ & $\begin{array}{l}\text { "Stepwise analyses were } \\
\text { conducted to establish a } \\
\text { factor structure of the } \\
\text { scale, revealing three } \\
\text { correlated factors: two } \\
\text { hedonic and one } \\
\text { eudaimonic." }\end{array}$ & $\begin{array}{l}\text { A three factor model } \\
\text { with hedonic pleasure, } \\
\text { hedonic comfort and } \\
\text { eudaimonic factors was } \\
\text { confirmed for motives } \\
\text { for activities. }\end{array}$ \\
\hline
\end{tabular}




\begin{tabular}{|c|c|c|c|c|c|c|}
\hline 8 & $\begin{array}{l}\text { Burns, Anstey, \& Windsor, } \\
2011\end{array}$ & $\begin{array}{l}\text { Are the related PWB } \\
\text { and SWB constructs } \\
\text { independent? }\end{array}$ & $\begin{array}{l}\text { lo } \\
N=3989 \text { randomly } \\
\text { selected individuals } \\
\text { from the electoral rolls } \\
\text { of Canberra/ } \\
\text { Queanbeyan, Australia. } \\
\text { Age= 20-24 \& 40-44 at } \\
\text { baseline }\end{array}$ & $\begin{array}{l}\text { Exploratory } \\
\text { Factor } \\
\text { Analysis } \\
\text { with } \\
\text { principal axis } \\
\text { factoring } \\
\text { with direct } \\
\text { oblimin } \\
\text { oblique } \\
\text { rotation } \\
\end{array}$ & $\begin{array}{l}\text { "Principal axis factoring } \\
\text { of the resilience, mastery, } \\
\text { and PANAS items } \\
\text { revealed a four-factor } \\
\text { structure whereby items } \\
\text { loaded onto factors that } \\
\text { corresponded with the } \\
\text { original measures." }\end{array}$ & $\begin{array}{l}\text { The measures reflect } \\
\text { different cognitive and } \\
\text { affective components of } \\
\text { well-being, whilst } \\
\text { moderate correlations } \\
\text { between these constructs } \\
\text { at a first-order factor } \\
\text { level, indicate PWB and } \\
\text { SWB as related. }\end{array}$ \\
\hline 9 & Compton, 2001 & $\begin{array}{l}\text { What is the factor } \\
\text { structure of well-being? }\end{array}$ & $\begin{array}{l}N=242 \text { participants } \\
\text { from the USA, } \\
\text { age }(M=25.9, S D=7.5)\end{array}$ & $\begin{array}{l}\text { Principal } \\
\text { Components } \\
\text { Analyses }\end{array}$ & $\begin{array}{l}\text { "A large first factor that } \\
\text { appeared to be a } \\
\text { subjective well-being } \\
\text { factor, a second factor } \\
\text { that seemed to be a } \\
\text { religiosity factor, and two } \\
\text { other factors that were } \\
\text { related to measures of } \\
\text { personal growth, } \\
\text { autonomy, and positive } \\
\text { relationships." }\end{array}$ & $\begin{array}{l}\text { A tripartite structure } \\
\text { with SWB, personal } \\
\text { growth \& religiosity that } \\
\text { is characterized by other- } \\
\text { centeredness. }\end{array}$ \\
\hline 10 & $\begin{array}{l}\text { Keyes, Shmotkin, \& Ryff, } \\
2002\end{array}$ & $\begin{array}{l}\text { Do indicators of PWB } \\
\text { and SWB constitute } \\
\text { taxonomically distinct } \\
\text { reflections of well- } \\
\text { being? }\end{array}$ & $\begin{array}{l}N=3032 \text { participants } \\
\text { from the USA. } \\
\text { Age(weighted })(M=45.3, \\
S D=13.5)\end{array}$ & $\begin{array}{l}\text { Exploratory } \\
\& \\
\text { Confirmatory } \\
\text { Factor } \\
\text { Analyses }\end{array}$ & $\begin{array}{l}\text { "The best fitting model is } \\
\text { one that posits two } \\
\text { correlated latent } \\
\text { constructs, namely SWB } \\
\text { and PWB, rather than two } \\
\text { orthogonal factors (or one } \\
\text { general factor)." }\end{array}$ & $\begin{array}{l}\text { SWB and PWB } \\
\text { represent related but } \\
\text { distinct conceptions of } \\
\text { well-being. }\end{array}$ \\
\hline 11 & $\begin{array}{l}\text { Chen, Jing, Hayes, \& Lee, } \\
2013\end{array}$ & $\begin{array}{l} \\
\text { Is there a meaningful } \\
\text { differentiation between } \\
\text { psychological well- } \\
\text { being and subjective } \\
\text { well-being? }\end{array}$ & $\begin{array}{l}\text { Study } 1: N=795 \\
\text { undergraduate } \\
\text { psychology students } \\
\text { from the university of } \\
\text { Delaware, } \\
\text { age }(M=19.27 \text {, } \\
S D=1.78) \text {. Study } 2: N= \\
4032 \text { Americans, } \\
\text { age }(M=56.25, \\
S D=12.39)\end{array}$ & $\begin{array}{l}\text { A bifactor } \\
\text { model }\end{array}$ & $\begin{array}{l}\text { "PWB and SWB form a } \\
\text { general factor of global } \\
\text { well-being, which } \\
\text { captures the common } \\
\text { ground shared by the two } \\
\text { types of well-being.[..] } \\
\text { the components of PWB } \\
\text { and of SWB form } \\
\text { specific factors, which } \\
\text { capture their unique } \\
\text { variances." }\end{array}$ & $\begin{array}{l}\text { "Both perspectives on } \\
\text { well-being have merit, } \\
\text { depending on the level of } \\
\text { analysis (i.e., general or } \\
\text { specific)." }\end{array}$ \\
\hline
\end{tabular}




\begin{tabular}{|c|c|c|c|c|c|c|}
\hline 12 & $\begin{array}{l}\text { Gallagher, Lopez, \& } \\
\text { Preacher, } 2009\end{array}$ & $\begin{array}{l}\text { What is the latent } \\
\text { structure of well-being? }\end{array}$ & $\begin{array}{l}N=591 \text { undergraduates } \\
\text { of a Mid-western } \\
\text { university, } \\
\text { age }(M=18.94, S D=1.65) \\
\& 4032 \text { American } \\
\text { Adults, age }(M=56.25, \\
S D=12.39) .\end{array}$ & $\begin{array}{l}\text { CFA } \\
\text { techniques }\end{array}$ & $\begin{array}{l}\text { "The model containing } \\
\text { three second-order } \\
\text { factors of hedonic, } \\
\text { eudaimonic, and social } \\
\text { well-being provided the } \\
\text { best representation of the } \\
\text { hierarchical structure of } \\
\text { well-being." }\end{array}$ & $\begin{array}{l}\text { A tripartite model with } \\
\text { hedonic, eudaimonic \& } \\
\text { social domains. }\end{array}$ \\
\hline 13 & Huta \& Ryan, 2010 & $\begin{array}{l}\text { How do hedonia and } \\
\text { eudaimonia (as motives } \\
\text { for activities) \& their } \\
\text { combination relate to } \\
\text { well-being? (only study } \\
1 \text { included) }\end{array}$ & $\begin{array}{l}N=300 \text { undergraduates } \\
\text { at a private northeastern } \\
\text { US university, } \\
\text { age }(M=19.7, S D=1.3) \text {. }\end{array}$ & $\begin{array}{l}\text { Principal } \\
\text { Components } \\
\text { Analysis, } \\
\text { MANOVA }\end{array}$ & $\begin{array}{l}\text { "The HEMA scales not } \\
\text { only confirmed the } \\
\text { distinction between } \\
\text { eudaimonia and hedonia, } \\
\text { but also had good } \\
\text { reliabilities for our } \\
\text { research." }\end{array}$ & $\begin{array}{l}\text { Hedonia and eudaimonia } \\
\text { occupy overlapping and } \\
\text { distinct niches. }\end{array}$ \\
\hline 14 & Kafka \& Kozma, 2002 & $\begin{array}{l}\text { What is the relationship } \\
\text { between Ryff's scale of } \\
\text { PWB and measures of } \\
\text { SWB? }\end{array}$ & $\begin{array}{l}N=277 \text { university } \\
\text { students at the } \\
\text { Memorial University of } \\
\text { Newfoundland and the } \\
\text { University of Winnipeg, } \\
\text { age }(M=21.31, S D= \\
3.76)\end{array}$ & $\begin{array}{l}\text { PCA with } \\
\text { varimax } \\
\text { rotation }\end{array}$ & $\begin{array}{l}\text { "While the MUNSH and } \\
\text { the SWLS loaded on the } \\
\text { same factor identifiable } \\
\text { as a higher order SWB } \\
\text { factor, subscales of the } \\
\text { SPWB produced two } \\
\text { additional factors." }\end{array}$ & $\begin{array}{l}\text { If the SPWB reflects } \\
\text { psychological } \\
\text { functioning, then it is } \\
\text { clear that such } \\
\text { functioning is not the } \\
\text { same as such SWB } \\
\text { constructs as } \\
\text { "happiness" or "life } \\
\text { satisfaction. }\end{array}$ \\
\hline 15 & Kim, Lehning, \& Sacco, 2016 & $\begin{array}{l}\text { Should hedonic and } \\
\text { eudaimonic } \\
\text { components of the } \\
\text { NHATS be measured } \\
\text { separately or on a single } \\
\text { scale? }\end{array}$ & $\begin{array}{l}N=6602 \text { older adults } \\
\text { (USA), ages } 65 \text { and } \\
\text { over }\end{array}$ & CFA & $\begin{array}{l}\text { "The single factor } \\
\text { structure indicates that } \\
\text { among community- } \\
\text { dwelling older adults in } \\
\text { the NHATS sample, the } \\
\text { hedonic and eudaimonic } \\
\text { aspects of well-being } \\
\text { may be intertwined." }\end{array}$ & $\begin{array}{l}\text { It appears that while } \\
\text { there is a conceptual } \\
\text { distinction between these } \\
\text { two views of well-being, } \\
\text { the hedonic and the } \\
\text { eudaimonic perspectives } \\
\text { can be measured as a } \\
\text { single scale. }\end{array}$ \\
\hline
\end{tabular}




\begin{tabular}{|c|c|c|c|c|c|c|}
\hline 16 & $\begin{array}{l}\text { Compton, Smith, Cornish, \& } \\
\text { Qualls, } 1996\end{array}$ & $\begin{array}{l}\text { What is the factor } \\
\text { structure of well-being? }\end{array}$ & $\begin{array}{l}N=338 \text { US students, } \\
\text { age }(M=25.8, S D=10.6)\end{array}$ & $\begin{array}{l}\text { Principal } \\
\text { Components } \\
\text { Analysis } \\
\text { with Oblique } \\
\text { rotation }\end{array}$ & $\begin{array}{l}\text { "Mental Health appears } \\
\text { to be defined by two } \\
\text { factors: SWB and } \\
\text { Personal Growth, with } \\
\text { SWB accounting for the } \\
\text { larger portion of variance } \\
\text { in the measures used for } \\
\text { this study" }\end{array}$ & $\begin{array}{l}\text { "Theories of personal } \\
\text { growth and subjective } \\
\text { well-being describe } \\
\text { related, but not identical, } \\
\text { constructs" }\end{array}$ \\
\hline 17 & $\begin{array}{l}\text { Kokko, Korkalainen, Lyyra, } \\
\text { \& Feldt, } 2013\end{array}$ & $\begin{array}{l}\text { What is the structure of } \\
\text { well-being? }\end{array}$ & $\begin{array}{l}N=219 \text { Finnish adults } \\
\text { at age } 36 \& 42\end{array}$ & \begin{tabular}{|l|} 
Structural \\
Equation \\
Modeling \\
\end{tabular} & $\begin{array}{l}\text { "Our findings showed } \\
\text { that well-being in mid- } \\
\text { adulthood can be } \\
\text { described in terms of a } \\
\text { higher-order core factor } \\
\text { comprising the three } \\
\text { dimensions from Keyes' } \\
\text { tripartite model of well- } \\
\text { being, that is, emotional, } \\
\text { psychological and social } \\
\text { well-being, as well as by } \\
\text { low depression." }\end{array}$ & $\begin{array}{l}\text { These results imply that } \\
\text { instead of following } \\
\text { separate lines of theory } \\
\text { and research, it is more } \\
\text { relevant to consider the } \\
\text { different dimensions of } \\
\text { well-being } \\
\text { simultaneously. }\end{array}$ \\
\hline 19 & Joshanloo, 2017* & $\begin{array}{l}\text { What is the structural } \\
\text { and discriminant } \\
\text { validity of the tripartite } \\
\text { model of mental well- } \\
\text { being? }\end{array}$ & $\begin{array}{l}N=2732 \text { US } \\
\text { participants, age }(M= \\
63.64, S D=11.35)\end{array}$ & $\begin{array}{l}\text { CFA \& } \\
\text { ESEM }\end{array}$ & $\begin{array}{l}\text { "Both in CFA and } \\
\text { ESEM, a three- } \\
\text { dimensional model of } \\
\text { mental well-being was } \\
\text { supported over the one- } \\
\text { and two-factor models." }\end{array}$ & $\begin{array}{l}\text { "Subjective, } \\
\text { psychological and social } \\
\text { dimensions of mental } \\
\text { well-being constitute } \\
\text { distinct factors, with a } \\
\text { substantial amount of } \\
\text { unshared variance." }\end{array}$ \\
\hline
\end{tabular}

*This author published three studies concerning the same research question in 2017 (with different populations), only one was included due to similar conclusions 
Table 5

Studies Focusing on Biological Measures/Genetics and SWB \& PWB

\begin{tabular}{|c|c|c|c|c|c|c|}
\hline $\mathrm{Nr}$ & Artikel & Research Question & Participants & Analysis & Outcome & $\begin{array}{l}\text { The structure of Well- } \\
\text { Being }\end{array}$ \\
\hline 20 & $\begin{array}{l}\text { Fredrickson et al., } \\
2013\end{array}$ & $\begin{array}{l}\text { What are the biological } \\
\text { implications of hedonic } \\
\& \text { eudaimonic well- } \\
\text { being? }\end{array}$ & $\begin{array}{l}N=80 \text { healthy adults from } \\
\text { Chapel Hill, NC, ages 35-64. }\end{array}$ & $\begin{array}{l}\text { Generalized } \\
\text { Linear Model } \\
\text { Analyses }\end{array}$ & $\begin{array}{l}\text { "Hedonic and eudaimonic } \\
\text { well-being, although } \\
\text { correlated, have markedly } \\
\text { divergent gene } \\
\text { transcriptional correlates in } \\
\text { human immune cells." }\end{array}$ & $\begin{array}{l}\text { The different streams of } \\
\text { well-being have a } \\
\text { different molecular } \\
\text { physiology. }\end{array}$ \\
\hline 21 & $\begin{array}{c}\longrightarrow \longrightarrow \\
\text { under debate! }\end{array}$ & $\begin{array}{l}\text { see Brown, MacDonald, } \\
\text { Samanta, Friedman, \& } \\
\text { Coyne, } 2014\end{array}$ & & & & \\
\hline 22 & $\begin{array}{l}\text { Fredrickson et al., } \\
2015\end{array}$ & $\begin{array}{l}\text { Is CTRA gene } \\
\text { expression associated } \\
\text { with eudaimonic (and } \\
\text { hedonic) well-being? }\end{array}$ & $\begin{array}{l}\text { Confirmation study }(\mathrm{CS}): N \\
=122 \text { adults from the } \\
\text { Durham and Orange County } \\
\text { regions of } \mathrm{NC} \text {, age }(M=48.4 \text {, } \\
S D=8.8) . \text { Generalization } \\
\text { study }(\mathrm{GS}): N=107 \\
\text { participants from the } \\
\text { Vancouver BC metropolitan } \\
\text { area, age }(M=45.3, S D=5.6)\end{array}$ & $\begin{array}{l}\text { Mixed effect } \\
\text { linear model } \\
\text { analyses to } \\
\text { predict } \\
\text { reduced } \\
\text { CRTA gene } \\
\text { expression } \\
\end{array}$ & $\begin{array}{l}\text { "Sub-dimensions of } \\
\text { eudaimonic well-being as } \\
\text { promising targets for CTRA } \\
\text { gene expression, and provide } \\
\text { no support for any } \\
\text { independent favorable } \\
\text { contribution from hedonic } \\
\text { well-being." }\end{array}$ & $\begin{array}{l}\text { Distinct molecular basis } \\
\text { for hedonic and } \\
\text { eudaimonic well-being. }\end{array}$ \\
\hline 23 & $\begin{array}{c}\longrightarrow \rightarrow \\
\text { under debate! }\end{array}$ & $\begin{array}{l}\text { see Brown, MacDonald, } \\
\text { Samanta, Friedman, \& } \\
\text { Coyne, } 2016\end{array}$ & & & & \\
\hline 24 & $\begin{array}{l}\text { Friedman, } \\
\text { Hayney, Love, } \\
\text { Singer, \& Ryff, } \\
2007\end{array}$ & $\begin{array}{l}\text { Can different measures } \\
\text { of well-being predict } \\
\text { plasma levels of } \\
\text { inflammatory factors in } \\
\text { aging women? }\end{array}$ & $\begin{array}{l}N=135 \text { aging women } \\
\text { (USA), age }(M=74.02, \\
S D=7.08)\end{array}$ & $\begin{array}{l}\text { Regression } \\
\text { analyses } \\
\text { between } \\
\text { plasma IL-6 \& } \\
\text { sIL-6R levels } \\
\text { and well-being } \\
\end{array}$ & $\begin{array}{l}\text { "The only measures that } \\
\text { were significantly related to } \\
\text { IL-6 and sIL-6R were } \\
\text { measures of eudaimonic } \\
\text { well-being." }\end{array}$ & $\begin{array}{l}\text { Distinct biomarkers for } \\
\text { hedonic and } \\
\text { eudaimonic well-being. }\end{array}$ \\
\hline 25 & Urry et al., 2004 & $\begin{array}{l}\text { What are the frontal } \\
\text { neural activation patterns } \\
\text { of eudaimonic and } \\
\text { hedonic well-being? }\end{array}$ & $\begin{array}{l}N=84 \text { adults who were } \\
\text { Wisconsin high school } \\
\text { seniors in } 1957, \\
\text { age }(M=58.49, S D=0.81)\end{array}$ & $\begin{array}{l}\text { Simultaneous } \\
\text { and } \\
\text { Hierarchical } \\
\text { Regression } \\
\text { Analysis }\end{array}$ & $\begin{array}{l}\text { Greater left than right } \\
\text { superior frontal activation } \\
\text { was positively associated } \\
\text { with both forms of well- } \\
\text { being, but only with PWB } \\
\text { when controlling for } \\
\text { dispositional positive affect. }\end{array}$ & $\begin{array}{l}\text { Both PWB and SWB } \\
\text { are associated with } \\
\text { greater left frontal } \\
\text { activation. }\end{array}$ \\
\hline
\end{tabular}




\begin{tabular}{|c|c|c|c|c|c|c|}
\hline 26 & $\begin{array}{l}\text { Ryff, Singer, \& } \\
\text { Love, } 2004\end{array}$ & $\begin{array}{l}\text { What are the biological } \\
\text { correlates of eudaimonic- } \\
\text { and hedonic well-being? }\end{array}$ & $\begin{array}{l}N=135 \text { aging women } \\
\text { (USA), age=61-91 }\end{array}$ & $\begin{array}{l}\text { Correlational } \\
\text { analysis }\end{array}$ & $\begin{array}{l}\text { "Eudaimonic and hedonic } \\
\text { well-being may not have } \\
\text { equivalent neurobiological } \\
\text { correlates" }\end{array}$ & $\begin{array}{l}\text { "There is a pressing } \\
\text { need to have measures } \\
\text { of both eudaimonic and } \\
\text { hedonic well-being } \\
\text { incorporated in } \\
\text { national-level health } \\
\text { statistics across } \\
\text { multiple countries." }\end{array}$ \\
\hline 27 & Keyes & $\begin{array}{l}\text { What is the structure of } \\
\text { the genetic and } \\
\text { environmental influences } \\
\text { on mental well-being? }\end{array}$ & $\begin{array}{l}N=670 \text { same-sex twins } \\
\text { pairs (USA) }+46 \text { individual } \\
\text { twins, age }(M=44.6 \text { years) }\end{array}$ & Twin & $\begin{array}{l}\text { "A common pathway model } \\
\text { fit our data best, suggesting } \\
\text { the existence of a latent } \\
\text { propensity to mental well- } \\
\text { being." }\end{array}$ & $\begin{array}{l}\text { "The tripartite structure } \\
\text { of well-being observed } \\
\text { at the phenotypic level } \\
\text { is caused by the latent, } \\
\text { higher-order variable of } \\
\text { mental well-being that } \\
\text { has its own genetic and } \\
\text { environmental } \\
\text { influences." }\end{array}$ \\
\hline 28 & $\begin{array}{l}\text { Steptoe, } \\
\text { Demakakos, de } \\
\text { Oliveira, \& } \\
\text { Wardle, } 2012\end{array}$ & $\begin{array}{l}\text { What is the relationship } \\
\text { between a range of } \\
\text { biological measures and } \\
\text { eudaimonic \& hedonic } \\
\text { well-being? }\end{array}$ & $\begin{array}{l}N=3540 \text { English men (age: } \\
M=65.6, S D=9.3 \text { ) \& } 4255 \\
\text { women (age: } M=65.6 \\
S D=9.7 \text { ). }\end{array}$ & $\begin{array}{l}\text { Multivariate } \\
\text { linear } \\
\text { regression }\end{array}$ & $\begin{array}{l}\text { There were few differences } \\
\text { in the associations between } \\
\text { biological function and } \\
\text { affective and eudaimonic } \\
\text { well-being. }\end{array}$ & $\begin{array}{l}\text { This study suggests that } \\
\text { both types of well- } \\
\text { being are similarly } \\
\text { related to a range of } \\
\text { biological measures. }\end{array}$ \\
\hline 29 & Walker, 2016 & $\begin{array}{l}\text { Can the results from } \\
\text { Fredrickson ( } 2013 \text { \& } \\
\text { 2015) regarding CTRA } \\
\text { expression levels and } \\
\text { well-being measures be } \\
\text { replicated using OLS \& } \\
\text { GEE (with Monte Carlo } \\
\text { simulation as a check for } \\
\text { performance)? }\end{array}$ & $\begin{array}{l}N=108 \text { participants from } \\
\text { Fredrickson, } 2013 \& 2015 \\
\text { (see above) }\end{array}$ & $\begin{array}{l}\text { Multivariate } \\
\text { (OLS) } \\
\text { linear models } \\
\text { and } \\
\text { generalized } \\
\text { estimating } \\
\text { equation } \\
\text { (GEE) models }\end{array}$ & $\begin{array}{l}\text { "The OLS estimates } \\
\text { combined with the } \\
\text { permutation F-tests provide } \\
\text { some evidence of a very } \\
\text { small negative association } \\
\text { between Eudaimonia and } \\
\text { mean CTRA expression, } \\
\text { although the Monte Carlo } \\
\text { results of these F tests raise } \\
\text { some concern about the sign } \\
\text { of this effect." }\end{array}$ & $\begin{array}{l}\text { CTRA gene expression } \\
\text { might only be related to } \\
\text { eudaimonia, but the } \\
\text { effect is very minor. }\end{array}$ \\
\hline
\end{tabular}


Figure 1. A roadmap of the different well-being constructs employed in this review.

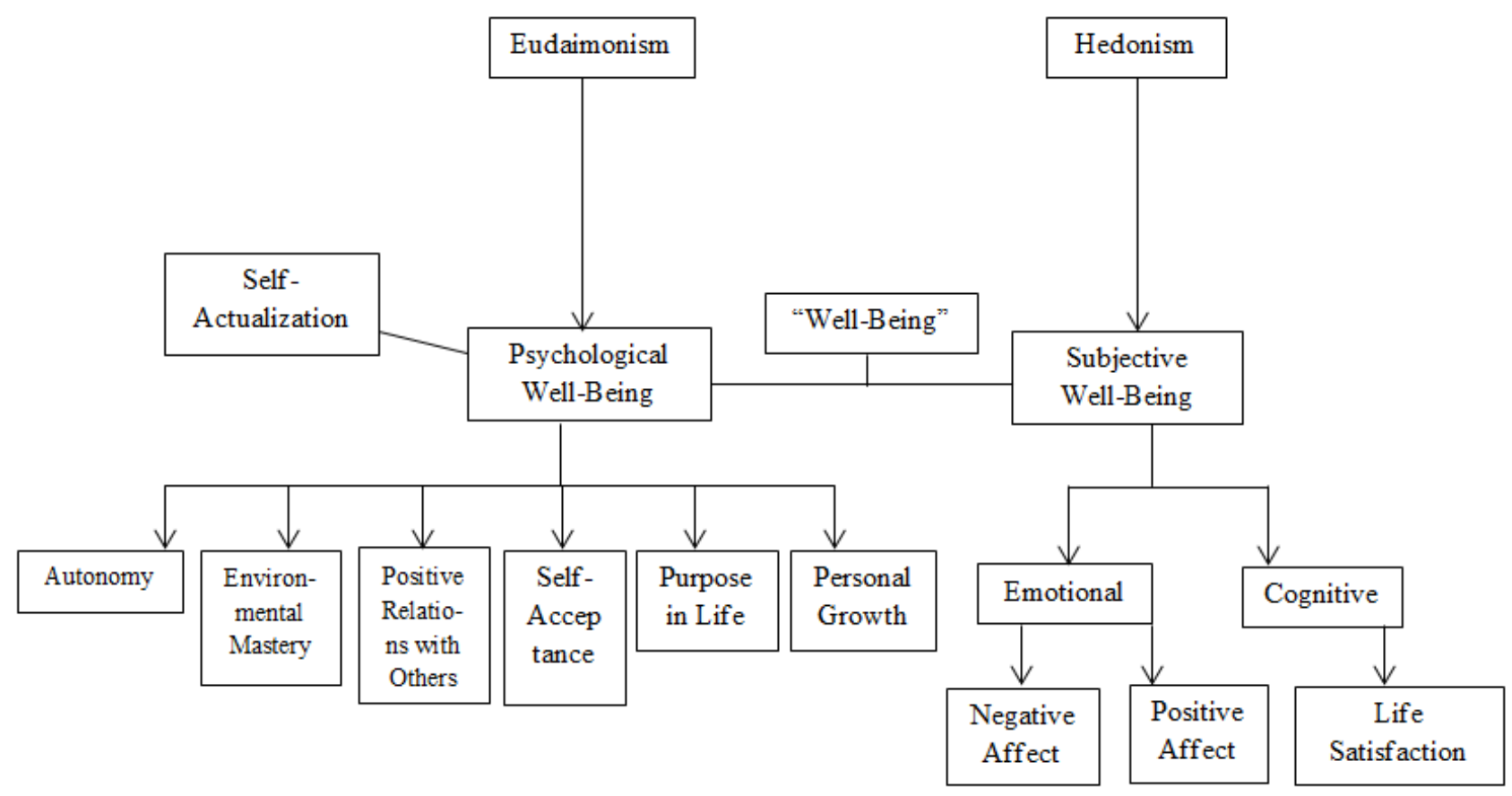


Figure 2. Flowchart for literature search.

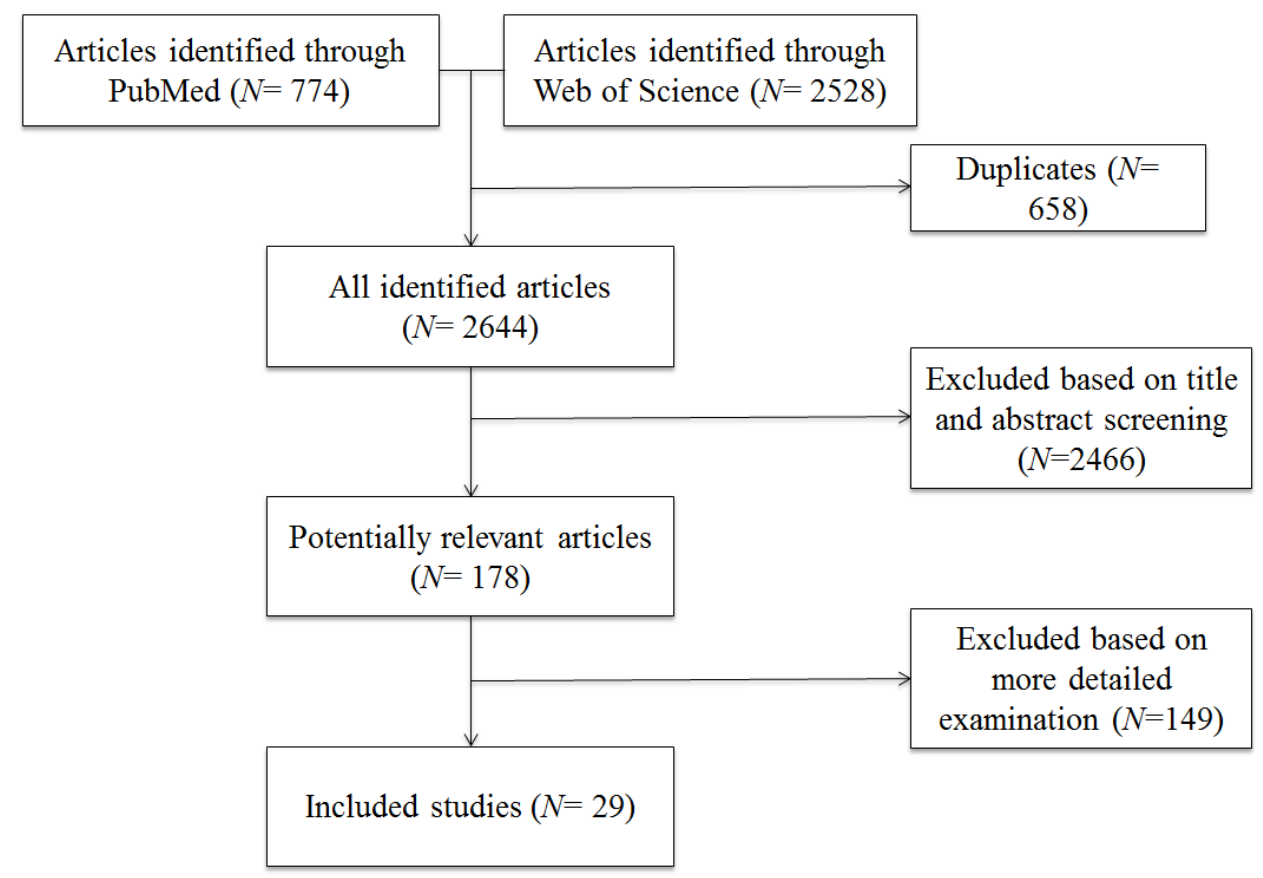




\section{References}

Aghababaei, N., \& Arji, A. (2014). Well-being and the HEXACO model of personality. Personality and Individual Differences, 56, 139-142.

Alexandrova, A. (2012). Well-Being as an object of science. Philosophy of Science, 79(5), 678-689.

Alexandrova, A. (2015). Well-being and philosophy of science. Philosophy Compass, 10(3), 219-231.

Berryman, S. (2016). Democritus. In E. N. Zalta (Ed.), The Stanford Encyclopedia of Philosophy (Winter 201). Metaphysics Research Lab, Stanford University.

Biswas-Diener, R., Kashdan, T. B., \& King, L. A. (2009). Two traditions of happiness research, not two distinct types of happiness. Journal of Positive Psychology, 4(3), 208-211.

Brown, N. J. L., MacDonald, D. A., Samanta, M. P., Friedman, H. L., \& Coyne, J. C. (2014). A critical reanalysis of the relationship between genomics and well-being. Proceedings of the National Academy of Sciences, 111(35), 12705-12709.

Brown, N. J. L., MacDonald, D. A., Samanta, M. P., Friedman, H. L., \& Coyne, J. C. (2016). More questions than answers: Continued critical reanalysis of Fredrickson et al.'s studies of genomics and well-being. PLoS One, 11(6).

Brülde, B. (2007). Happiness theories of the good life. Journal of Happiness Studies, 8(1), 15-49.

Bujacz, A., Vitterso, J., Huta, V., \& Kaczmarek, L. D. (2014). Measuring hedonia and eudaimonia as motives for activities: Cross-national investigation through traditional and Bayesian structural equation modeling. Frontiers in Psychology, 5.

Burns, R. A., Anstey, K. J., \& Windsor, T. D. (2011). Subjective well-being mediates the effects of resilience and mastery on depression and anxiety in a large community sample of young and middleaged adults. Australian and New Zealand Journal of Psychiatry, 45(3), 240-248. 
RUNNING HEAD: a literature review on the complex framework well-being

Chen, F. F., Jing, Y., Hayes, A., \& Lee, J. M. (2013). Two concepts or two approaches? A bifactor analysis of psychological and subjective well-being. Journal of Happiness Studies, 14(3), 10331068.

Compton, W. C. (2001). Toward a tripartite factor structure of mental health: Subjective well-being, personal growth, and religiosity. Journal of Psychology, 135(5), 486-500.

Compton, W. C., Smith, M. L., Cornish, K. A., \& Qualls, D. L. (1996). Factor structure of mental health measures. Journal of Personality and Social Psychology, 71(2), 406-413.

Crimmins, J. E. (2017). Jeremy Bentham. In E. N. Zalta (Ed.), The Stanford Encyclopedia of Philosophy (Spring 201). Metaphysics Research Lab, Stanford University.

Deijl, W. van der. (2016). Are measures of well-being philosophically adequate? Philosophy of the Social Sciences, 47(3), 209-234.

Diener, E. (1984). Subjective well-being. Psychological Bulletin, 95(3), 542-75.

Diener, E. (1994). Assessing subjective well-being: Progress and opportunities. Social Indicators Research, 31(2), 103-157.

Diener, E., Emmons, R. A., Larsen, R. J., \& Griffin, S. (1985). The Satisfaction with life scale. Journal of Personality Assessment, 49(1), 71-75.

Dodge, R., Daly, A. P., Huyton, J., \& Sanders, L. D. (2012). The challenge of defining well-being. International Journal of Well-being, 2(3).

Feldman, F. (2010). What is this thing called happiness? Oxford University Press.

Fowers, B. J., \& Lefevor, G. T. (2015). The inescapability of intersubjectivity in meaning. American Psychologist, 70(6), 573-574. 
Fredrickson, B. L., Grewen, K. M., Algoe, S. B., Firestine, A. M., Arevalo, J. M. G., Ma, J., \& Cole, S. W. (2015). Psychological well-being and the human conserved transcriptional response to adversity. PLoS One, 10(3).

Fredrickson, B. L., Grewen, K. M., Coffey, K. A., Algoe, S. B., Firestine, A. M., Arevalo, J. M. G., ... Cole, S. W. (2013). A functional genomic perspective on human well-being. Proceedings of the National Academy of Sciences, 110(33), 13684-13689.

Friedman, E. M., Hayney, M., Love, G. D., Singer, B. H., \& Ryff, C. D. (2007). Plasma interleukin-6 and soluble IL-6 receptors are associated with psychological well-being in aging women. Health Psychology, 26(3), 305-313.

Gallagher, M. W., Lopez, S. J., \& Preacher, K. J. (2009). The hierarchical structure of well-being. Journal of Personality, 77(4), 1025-1050.

Huta, V., \& Ryan, R. M. (2010). Pursuing pleasure or virtue: The differential and overlapping well-being benefits of hedonic and eudaimonic motives. Journal of Happiness Studies, 11(6), 735-762.

Joshanloo, M. (2014). Eastern conceptualizations of happiness: Fundamental differences with Western views. Journal of Happiness Studies, 15(2), 475-493.

Joshanloo, M. (2016). Revisiting the empirical distinction between hedonic and eudaimonic aspects of well-being using exploratory structural equation modeling. Journal of Happiness Studies, 17(5), 2023-2036.

Joshanloo, M. (2017). Structural and discriminant validity of the tripartite model of mental well-being: Differential relationships with the big five traits. Journal of Mental Health, 1-7.

Kafka, G. J., \& Kozma, A. (2002). The construct validity of Ryff's scales of psychological well-being (SPWB) and their relationship to measures of subjective well-being. Social Indicators Research, 
RUNNING HEAD: a literature review on the complex framework well-being

57(2), 171-190.

Kashdan, T. B., Biswas-Diener, R., \& King, L. A. (2008). Reconsidering happiness: the costs of distinguishing between hedonics and eudaimonia. The Journal of Positive Psychology, 3(4), 219233.

Keyes, C. L. M., Myers, J. M., \& Kendler, K. S. (2010). The structure of the genetic and environmental influences on mental well-being. American Journal of Public Health, 100(12), 2379-2384.

Keyes, C. L. M., Shmotkin, D., \& Ryff, C. D. (2002). Optimizing well-being: The empirical encounter of two traditions. Journal of Personality and Social Psychology, 82(6), 1007-1022.

Keyes, C. L. M., \& Waterman, M. B. (2003). Dimensions of well-being and mental health in adulthood. Lawrence Erlbaum Associates Publishers.

Kim, K., Lehning, A. J., \& Sacco, P. (2016). Assessing the factor structure of well-being in older adults: Findings from the National Health and Aging Trends Study. Aging \& Mental Health, 20(8), 814822.

Kokko, K., Korkalainen, A., Lyyra, A.-L., \& Feldt, T. (2013). Structure and continuity of well-being in mid-adulthood: A longitudinal study. Journal of Happiness Studies, 14(1), 99-114.

Lambert, L., Passmore, H.-A., \& Holder, M. D. (2015). Foundational frameworks of positive psychology: Mapping well-being orientations. Canadian Psychology/Psychologie Canadienne, 56(3), 311-321.

Linton, M.-J., Dieppe, P., \& Medina-Lara, A. (2016). Review of 99 self-report measures for assessing well-being in adults: exploring dimensions of well-being and developments over time. BMJ Open, 6(7), e010641.

Maslow, A. H., \& H., A. (1943). A theory of human motivation. Psychological Review, 50(4), 370-396.

McMahan, E. A., \& Estes, D. (2011). Hedonic versus eudaimonic conceptions of well-being: Evidence of 
differential associations with self-reported well-being. Social Indicators Research, 103(1), 93-108.

McMahon, D. M. (2016). Living well in light of science. Annals of the New York Academy of Sciences, 1384(1), 36-38.

Nave, C. S., Sherman, R. A., \& Funder, D. C. (2008). Beyond self-report in the study of hedonic and eudaimonic well-being: Correlations with acquaintance reports, clinician judgments and directly observed social behavior. Journal of Research in Personality, 42(3), 643-659.

Robitschek, C., \& Keyes, C. L. M. (2009). Keyes's model of mental health with personal growth initiative as a parsimonious predictor. Journal of Counseling Psychology, 56(2), 321-329.

Ryan, R. M., \& Deci, E. L. (2000). Self-determination theory and the facilitation of intrinsic motivation, social development, and well-being. American Psychologist, 55(1), 68-78.

Ryff, C. D. (2014). Psychological well-being revisited: advances in the science and practice of eudaimonia. Psychotherapy and Psychosomatics, 83(1), 10-28.

Ryff, C. D., \& Keyes, C. L. M. (1995). The structure of psychological well-being revisited. Journal of Personality and Social Psychology, 69(4), 719-727.

Ryff, C. D., \& Singer, B. H. (2008). Know thyself and become what you are: A eudaimonic approach to psychological well-being. Journal of Happiness Studies, 9(1), 13-39.

Ryff, C. D., Singer, B. H., \& Love, G. D. (2004). Positive health: Connecting well-being with biology. Philosophical Transactions-Royal Society of London Series B Biological Sciences, 359(1449), $1383-1394$.

Sanjuan, P. (2011). Affect balance as mediating variable between effective psychological functioning and satisfaction with life. Journal of Happiness Studies, 12(3), 373-384.

Steptoe, A., Demakakos, P., de Oliveira, C., \& Wardle, J. (2012). Distinctive biological correlates of 
RUNNING HEAD: a literature review on the complex framework well-being

positive psychological well-being in older men and women. Psychosomatic Medicine, 74(5), 501508.

Tännsjö, T. (2007). Narrow hedonism. Journal of Happiness Studies, 8(1), 79-98.

Urry, H. L., Nitschke, J. B., Dolski, I., Jackson, D. C., Dalton, K. M., Mueller, C. J., ... Davidson, R. J. (2004). Making a life worth living - Neural correlates of well-being. Psychological Science, 15(6), $367-372$.

Vanhoutte, B., \& Nazroo, J. (2014). Cognitive, affective and eudemonic well-being in later life: Measurement equivalence over gender and life stage. Sociological Research Online, 19(2).

Veenhoven, R. (1984). Conditions of happiness. Springer Science \& Business Media.

Vitters $\emptyset$, J. (Ed.). (2016). Handbook of eudaimonic well-being. International handbooks of quality-of-life.

Walker, J. A. (2016). Monte Carlo simulation of OLS and linear mixed model inference of phenotypic effects on gene expression. PeerJ, 4.

Warren, M. A., \& Donaldson, S. I. (Stewart I. (2017). Evaluating scientific advances in positive psychology. Santa Barbara, California: Praeger.

Waterman, A. S. (1993). Two conceptions of happiness: Contrasts of personal expressiveness (eudaimonia) and hedonic enjoyment. Journal of Personality and Social Psychology, 64(4), 678691.

Waterman, A. S., \& S., A. (1990). The relevance of Aristotle's conception of eudaimonia for the psychological study of happiness. Theoretical \& Philosophical Psychology, 10(1), 39-44.

West, H. R. (2004). An introduction to Mill's utilitarian ethics. Cambridge University Press. 